\title{
S45C 調質材の二段多重変動荷重下の回転曲げ疲労寿命評価
}

\author{
高瀬 徹 ${ }^{* 1}$, 小山 敦弘 ${ }^{* 1}$, 内田 武 ${ }^{* 2}$
}

\section{Estimation of fatigue life on heat-treated $0.45 \% \mathrm{C}$ steel under repeated two-step variable amplitude loading}

\author{
Toru TAKASE ${ }^{* 1}$, Atsuhiro KOYAMA ${ }^{* 1}$ and Takeshi UCHIDA ${ }^{* 2}$ \\ ${ }^{* 1}$ Graduate School of Engineering, Nagasaki University \\ 1-14 Bunkyomachi, Nagasaki-shi, Nagasaki 852-8521, Japan \\ ${ }^{*}$ Department of Creative Engineering, National Institute of Technology, Kitakyushu College \\ 5-20-1 Shii, Kokuraminami-ku, Kitakyushu-shi, Fukuoka 802-0985, Japan
}

Received: 1 November 2017; Revised: 18 December 2017; Accepted: 4 January 2018

\begin{abstract}
In order to design a rotating shaft, it is necessary to investigate the fatigue characteristics under the variable amplitude loading by using a rotating bending fatigue machine. However, the stress amplitude cannot be changed frequently in a commercial rotating bending fatigue machine. Therefore, the automatic loading apparatus was manufactured in order to perform the fatigue test under the repeated two-step variable amplitude loading by using the commercial rotating bending fatigue machine. In this apparatus, the load was changed by loading or unloading the weight using air pressure. The high stress amplitude and the low stress amplitude were alternately applied to the specimen in the rotating bending fatigue test under repeated two-step variable amplitude loading. Rotating bending fatigue tests were performed using heat-treated $0.45 \% \mathrm{C}$ steel specimens. Before the fatigue tests, the performance test of the automatic loading apparatus was conducted and it was found that the apparatus was available for fatigue tests. Next, the fatigue tests under the repeated two-step variable amplitude loading were carried out based on the results in the Hi-Lo two-step loading fatigue test and then the cumulative fatigue was investigated. The total fatigue lives to failure of low stress amplitude under the repeated two-step variable amplitude loading are almost same as lives under the HiLo two-step loading, but they have the longer lives as the low stress amplitudes decrease. Finally, the life prediction method for the specimens subjected to repeated two-step variable amplitude loading was proposed. The results estimated based on the proposed method were in good agreement with the experimental ones.
\end{abstract}

Keywords : Fatigue, Life prediction, Cumulative fatigue damage, Variable amplitude loading, Rotating bending fatigue

\section{1. 緒言}

構造物あるいは機械の長期信頼性向上のためには，疲労強度を把握する必要があるそその中でも実働荷重下の 疲労強度を把握することは重要であるため, 荷重の種類，大きさ，あるいは頻度など組合せを変えて多くの研究 が行われてきた（Murthy et al., 2004）。また，実働荷重下の疲労寿命評価については，Miner が線形累積損傷則い わゆるマイナー則を提案 (Miner, 1945) して以降, 多くの研究者によりさまざまな方法が提案されている. 特に, 疲労限度以下の応力振幅を含む場合に関する研究では， $S-N$ 曲線を基とした方法，たとえば $S-N$ 曲線の有限寿命 域を疲労限度以下にまで延長した修正マイナ一則，有限寿命域の傾きを変えた Corten-Dolan の方法などがある. また，菊川らは，一般の実働荷重の場合に安全側の推定を与える限界修正 $S-N$ 曲線を二段繰返し変動荷重疲労試 験の結果より提案し，その有用性を確かめている（菊川他，1974）。一方で，疲労き裂に着目し寿命評価法を検討

\footnotetext{
No.17-00489 [DOI:10.1299/transjsme.17-00489], J-STAGE Advance Publication date : 19 January, 2018

${ }^{* 1}$ 正員, 長崎大学大学院工学研究科（广852-8521 長崎県長崎市文教町 1-14)

*2 正員, 北九州工業高等専門学校生産デザイン工学科（下802-0985 福岡県北九州市小倉南区志井 5-20-1）

E-mail of corresponding author: takase@nagasaki-u.ac.jp
} 
した研究もあり，たとえば，村上らは二段繰返し疲労試験を行い，応力振幅切替え時のき裂長さに注目し，過小 応力とき裂長さとの相互関係により累積疲労損傷值がどのようにでも変わりうることを示している(村上, 松田, 1987)。また, 川久保らは疲労損傷過程におけるき裂の発生・成長と繰返し軟化／硬化挙動に着目し, 試験途中で 表面を除去しながら試験を行い，き裂および軟化／硬化挙動が疲労寿命に及ぼす影響を考察している（川久保， 釜谷, 2011).しかし, これらの研究の多くは引張り負荷によるものであり, 回転軸の設計に有用な回転曲げに関 するものは少ないようである（村上, 松田, 1987). 著者らも高一低二段二重変動荷重下の回転曲げ試験を行い, これまでに簡便な寿命評価法を提案している (高瀬, 2009)。しかし, 市販の回転曲げ疲労試験機を用いて変動荷 重下の疲労試験を行う場合には, 所定の回数ごとに試験機を停止し, 手動により負荷荷重を変える必要がある. これは非常に煩雑で時間に拘束される操作となるだけではなく, 負荷および除荷時に想定外の負荷が加わる危険 性が生じることとなる，そこで，本研究では，まず，回転曲げ疲労試験機を用いて効率良く疲労試験を行うため に，自動で負荷荷重を変えることができる装置を製作した，その後，製作した装置を用いて二段多重変動荷重疲 労試験を行い, 疲労寿命評価を行った. さらに, 疲労寿命および累積疲労損傷值に及ぼす応力振幅の切替え頻度 の影響についても検討した.

\section{2. 自動負荷装置}

\section{$2 \cdot 1$ 負荷機構}

自動負荷装置の負荷機構の概略を図 1 に示寸. 小野式回転曲げ疲労試験機の既存のおもり受皿の下方に受血を 一つ増設し，おもり昇降血（Weight lifter）を上下させ，増設した受血に載せたおもりのみを上下させることによ り, 荷重を変動させた.おもり昇降皿を上下させるための駆動源には, 設置場所, 装置の簡便性および現有設備 の利用を考慮し, 空気圧を利用したエアシリンダーを用いた. エアシリンダーの空気の流れは電磁弁により切替 えた。またエアシリンダーの移動距離は $8 \mathrm{~mm}$ に設定した。

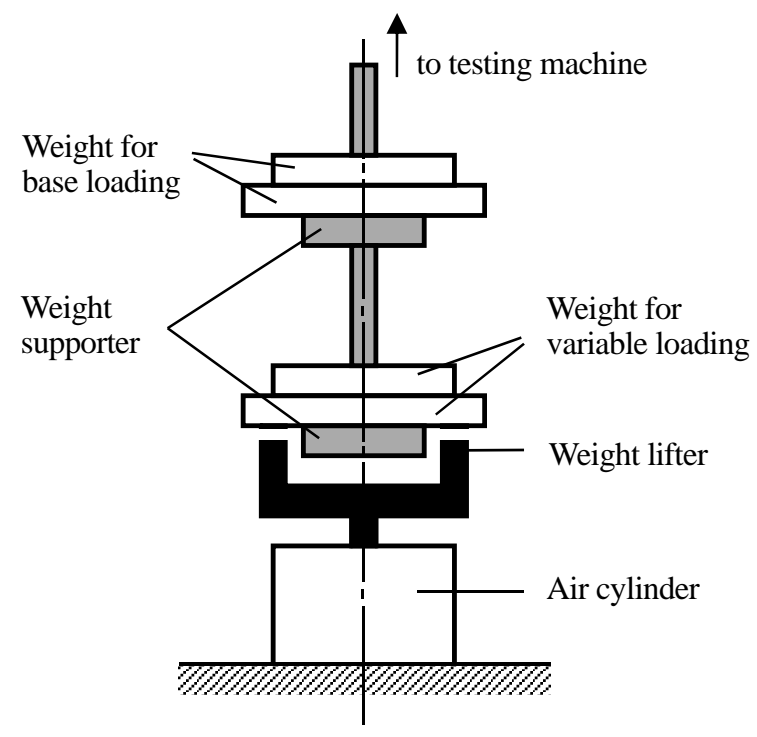

Fig.1 Schematic illustration of loading mechanism. The weight lifter is moved up and down. The load was changed by loading or unloading the weight using air pressure.

\section{$2 \cdot 2$ 繰返し数の計数およびエアシリンダーの制御}

荷重を切替えるタイミングは，試験機の回転軸の積算回転数を計測し，設定した回数になったときとし，その ときに $2 \cdot 1$ で述べたおもり昇降血を上下させた. 繰返し数の計数には, 光透過型フォトインタラプタとカウンタ 


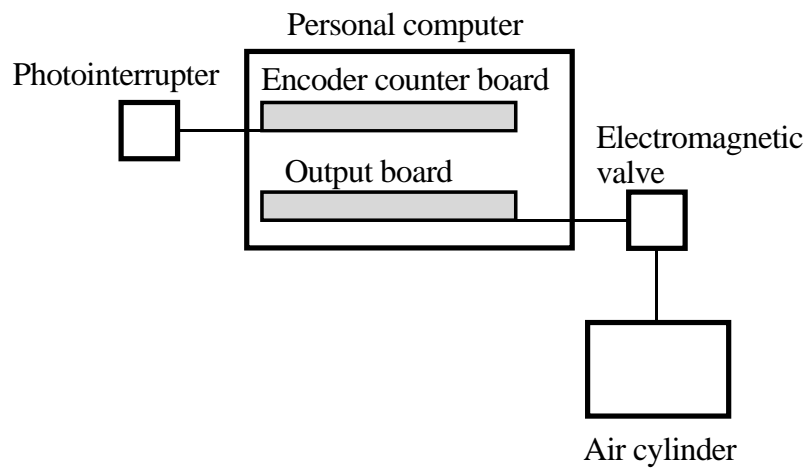

Fig.2 Schematic illustration of control unit.

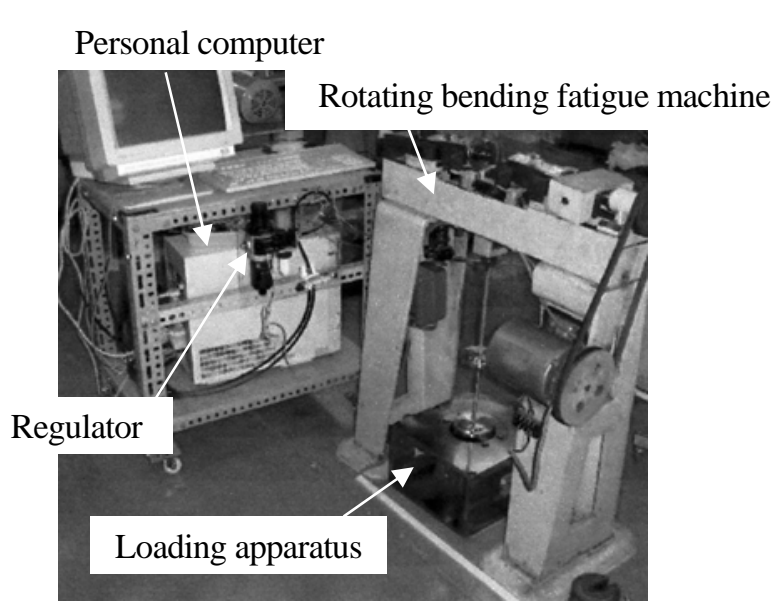

(a) Overview of test equipment

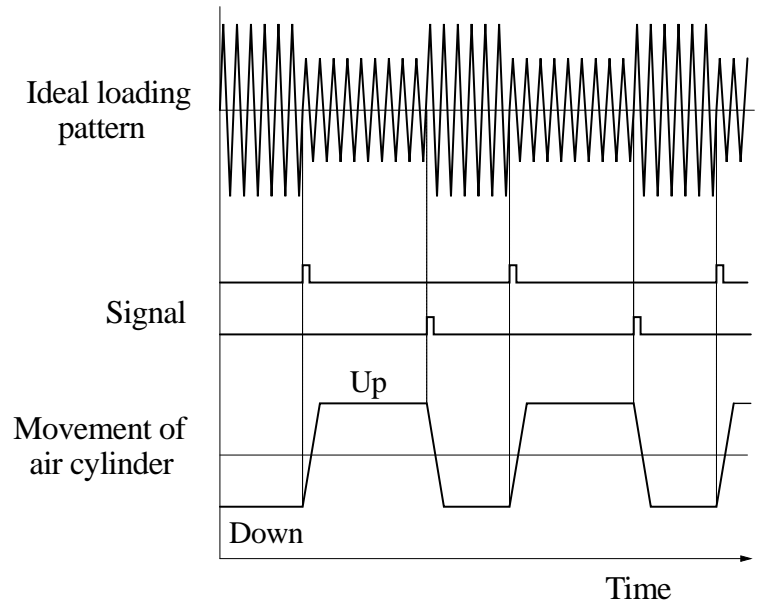

Fig.3 Time chart. Since the air cylinder starts moving when a pulse signal is generated, a time lag of loading or unloading occurs.

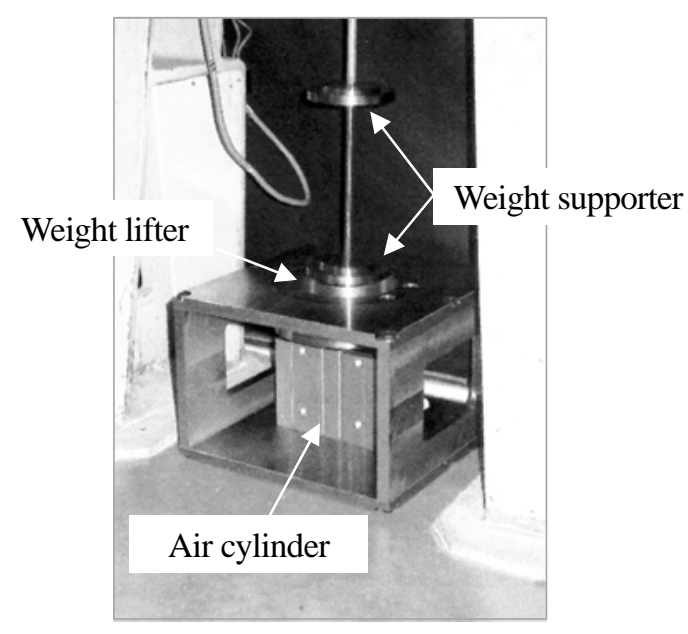

(b) Loading apparatus

Fig.4 Ono-type rotating bending fatigue test machine and loading apparatus: (a) overview of test equipment; (b) loading apparatus. Only the weight on the lower weight supporter is loaded and unloaded by the weight lifter.

ボードを組み合わせたものを使用した。ここでカウントされた繰返し数を基に変動荷重の負荷および除荷のタイ ミングを制御した。エアシリンダーの制御系の概要を図 2 に示す. 所定の繰返し数に達したときに出力ボードか らパルス信号を出す。この信号により電磁弁が作動し，最終的におもり昇降血が上下し荷重を変動させる。その 際，急激な除荷および負荷による振動を避けるために，昇降皿の上下の移動はゆっくりと行った。図 3 は所望の 荷重パターンに対する信号の発生時期およびそのときのエアシリンダーの上下方向への移動の様子を模式的に示 したタイムチャートである。図からわかるように，エアシリンダーの移動には時間が必要であるため，荷重の変 動は理想的な負荷パターンにはならず，荷重が完全に切り替わるためには約 1 秒が必要となった。しかし，この 時間は繰返し数に換算すると 60 回程度であり, 手動で荷重を変動させる場合にも，同様な状態になっていると考 えられるため，これが無視できる繰返し数で荷重を切替えれば実用上は問題にはならないとした．図 4 に使用し

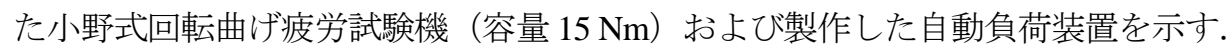


Table 1 Chemical composition (wt\%).

\begin{tabular}{c|c|c|c|c|c|c|c}
\hline \hline $\mathrm{C}$ & $\mathrm{Si}$ & $\mathrm{Mn}$ & $\mathrm{P}$ & $\mathrm{S}$ & $\mathrm{Cu}$ & $\mathrm{Ni}$ & $\mathrm{Cr}$ \\
\hline 0.44 & 0.19 & 0.77 & 0.024 & 0.015 & 0.02 & 0.03 & 0.14 \\
\hline
\end{tabular}

Table 2 Mechanical properties.

\begin{tabular}{c|c|c|c|c}
\hline \hline $\begin{array}{c}\sigma_{0.2} \\
\mathrm{MPa}\end{array}$ & $\begin{array}{c}\sigma_{\mathrm{B}} \\
\mathrm{MPa}\end{array}$ & $\begin{array}{c}\sigma_{\mathrm{T}} \\
\mathrm{MPa}\end{array}$ & $\begin{array}{c}\delta \\
\%\end{array}$ & $\begin{array}{c}\phi \\
\%\end{array}$ \\
\hline 486 & 743 & 1459 & 24.4 & 64.9 \\
\hline
\end{tabular}

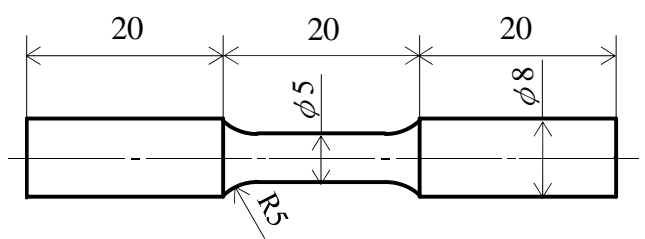

Fig.5 Configuration and dimensions of specimen.

\section{3. 疲労試験}

\section{$3 \cdot 1$ 供試材料および試験片}

供試材料は市販の $\mathrm{S} 45 \mathrm{C}$ 厓延丸棒（直径 $25 \mathrm{~mm}$ ）であり，それを $845^{\circ} \mathrm{C} \times 30 \mathrm{~min}$ の焼入れのあと， $600^{\circ} \mathrm{C} \times 1 \mathrm{~h}$ の 焼戻しを行った. 化学成分を表 1 に示寸. 熱処理後の引張試験によって得られた機械的性質を表 2 に示寸. また, 試験片の形状および寸法を図 5 に示す，すべての試験片は，機械加工層を除去するため，直径 $5 \mathrm{~mm}$ の平行部の 表面層を電解研磨により約 $50 \mu \mathrm{m}$ 除去し試験に供した.

\section{$3 \cdot 2$ 試験条件}

著者らは，一次応力振幅の大きさおよびその繰返し数を変えた高一低二段二重変動荷重疲労試験を行い，図 6 のように， $D_{1}$ と $m_{2}$ の関係は，ほぼ一直線で表されることを示した。 ここで， $D_{1}$ は応力振幅を切替える時点での 一次応力振幅 $\sigma_{1}$ による疲労損傷值（= 一次応力振幅の繰返し数 /一次応力振幅のみを繰返した場合の疲労寿命）

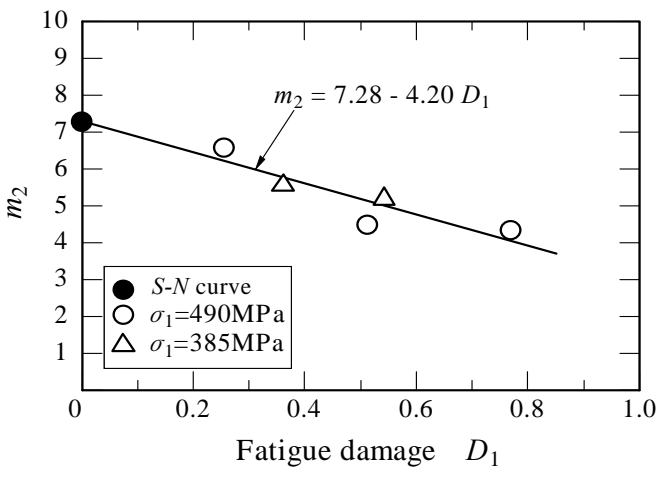

Fig.6 $m_{2}$ vs. $D_{1}$. The relation between $m_{2}$ and $D_{1}$ is represented by a straight line (Takase, 2009).

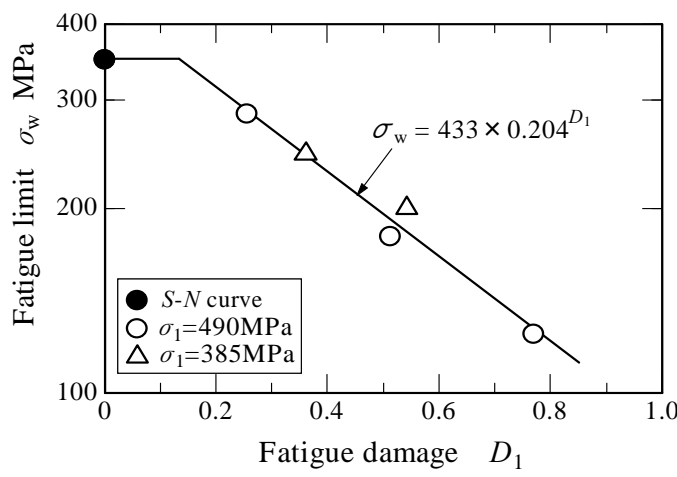

Fig.7 $\sigma_{\mathrm{w}}$ vs. $D_{1}$. The relation between $m_{2}$ and $D_{1}$ is represented by a straight line (Takase, 2009). 
であり, $m_{2}$ は応力振幅切替え後の二次応力振幅 $\sigma_{2}$ とその応力振幅の下での疲労寿命との関係を表す直線の傾き である. また, 図 7 のように, $D_{1}$ と二次応力振幅の下での非破断の上限值である $\sigma_{\mathrm{w}}$ の関係もほぼ一直線で表され ることを示した. そこで, これらの関係より高一低二段二重変動疲労の場合の疲労寿命評価法を提案し, 妥当な 結果が得られることを報告した（高瀬，2009）。つまり，この方法によると， $\sigma_{1}$ を $n_{1}$ 回繰返した場合の $D_{1}$ に対す る $m_{2}$ および $\sigma_{\mathrm{w}}$ を図 6 および図 7 より求め, $\sigma_{2}$ での疲労寿命 $n_{2}$ を推定することができる.

上で述べた疲労寿命評価法により推定された高一低二段二重変動荷重下の疲労寿命を基に設定した二段多重変 動荷重疲労試験の条件を表 3 に示す． 2 種類の応力振幅を交互に繰返すが，そのうちの高応力振幅 $\sigma_{\mathrm{H}}$ を $490 \mathrm{MPa}$ (未使用材の疲労限度の 1.4 倍) の一定とし, 低応力振幅 $\sigma_{\mathrm{L}}$ のみを変化させた. また, それぞれの応力振幅の繰返

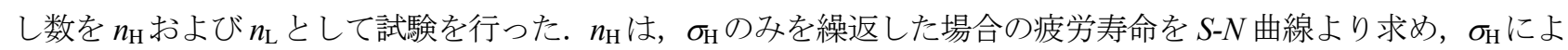
る疲労損傷值を 0.256 として算出したものを分割数 $n_{\mathrm{b}}(=2,4,8)$ で除した繰返し数である. ただし, 試験機の積算 回転数の表示が 100 回単位であるため, 手動による荷重の切替えと合わせるために, $n_{\mathrm{H}}$ は 2500, 1200 および 600 回とした. $n_{\mathrm{L}}$ は, 疲労損傷值 $D_{1}=0.256$ の場合について, $\sigma_{2}=\sigma_{\mathrm{L}}$ として高一低二段二重変動疲労の場合の $\sigma_{2}$ での疲 労寿命 $n_{2}$ を図 6 および図 7 より推定し，その $n_{2}$ を $n_{\mathrm{b}}$ で除した繰返し数である. $n_{\mathrm{b}}$ が大きくなることは, 応力振 幅の切替え頻度が多いことを意味する. 既報で $D_{1}$ を変化させて累積疲労損傷值 $D_{\mathrm{f}}$ を推定した場合, $D_{1}=0.5$ を 境にして $\sigma$ の $D_{\mathrm{f}}$ への影響が異なり， $D_{1}$ が 0.5 より小さいと $\sigma_{\mathrm{L}}$ 低下とともに $D_{\mathrm{f}}$ が小さくなることがわか った (瀬戸口他, 2000). そこで， $D_{1}$ が小さいときの $D_{1}$ に及ぼす応力振幅の切り換え頻度の影響を検討す るため, ここでは $D_{1}$ を 0 と 0.5 の間の 0.256 とした，なお，す心゙ての疲労試験における繰返し速度は $60 \mathrm{~Hz}$ と した.

まず，自作した自動負荷装置の有用性を確認するための予備試験を行った．予備試験では，表 3 に示寸試験条 件のうち, すべての分割数において $\sigma$ を 350,200 および $150 \mathrm{MPa}$ の 3 種類とした. 図 8 に低応力振幅 $\sigma$ と全繰

Table 3 Test conditions.

\begin{tabular}{|c|c|c|c|c|c|c|c|c|c|c|c|}
\hline \multicolumn{4}{|c|}{$n_{\mathrm{b}}=2$} & \multicolumn{4}{|c|}{$n_{\mathrm{b}}=4$} & \multicolumn{4}{|c|}{$n_{\mathrm{b}}=8$} \\
\hline $\begin{array}{c}\sigma_{\mathrm{H}} \\
\mathrm{MPa}\end{array}$ & $n_{\mathrm{H}}$ & $\begin{array}{c}\sigma_{\mathrm{L}} \\
\mathrm{MPa} \\
\end{array}$ & $n_{\mathrm{L}}$ & $\begin{array}{c}\sigma_{\mathrm{H}} \\
\mathrm{MPa}\end{array}$ & $n_{\mathrm{H}}$ & $\begin{array}{c}\sigma_{\mathrm{L}} \\
\mathrm{MPa}\end{array}$ & $n_{\mathrm{L}}$ & $\begin{array}{c}\sigma_{\mathrm{H}} \\
\mathrm{MPa} \\
\end{array}$ & $n_{\mathrm{H}}$ & $\begin{array}{c}\sigma_{\mathrm{L}} \\
\mathrm{MPa}\end{array}$ & $n_{\mathrm{L}}$ \\
\hline \multirow{6}{*}{490} & \multirow{6}{*}{2500} & 420 & $1.76 \times 10^{4}$ & \multirow{6}{*}{490} & \multirow{6}{*}{1200} & 420 & $8.80 \times 10^{3}$ & \multirow{6}{*}{490} & \multirow{6}{*}{600} & 420 & $4.40 \times 10^{3}$ \\
\hline & & 350 & $5.62 \times 10^{4}$ & & & 350 & $2.81 \times 10^{4}$ & & & 350 & $1.40 \times 10^{4}$ \\
\hline & & 285 & $2.08 \times 10^{5}$ & & & 285 & $1.04 \times 10^{5}$ & & & 285 & $5.20 \times 10^{4}$ \\
\hline & & 250 & $4.80 \times 10^{5}$ & & & 250 & $2.40 \times 10^{5}$ & & & 250 & $1.20 \times 10^{5}$ \\
\hline & & 200 & $1.99 \times 10^{6}$ & & & 200 & $9.94 \times 10^{5}$ & & & 200 & $4.97 \times 10^{5}$ \\
\hline & & 150 & $1.24 \times 10^{7}$ & & & 150 & $6.22 \times 10^{6}$ & & & 150 & $3.11 \times 10^{6}$ \\
\hline
\end{tabular}

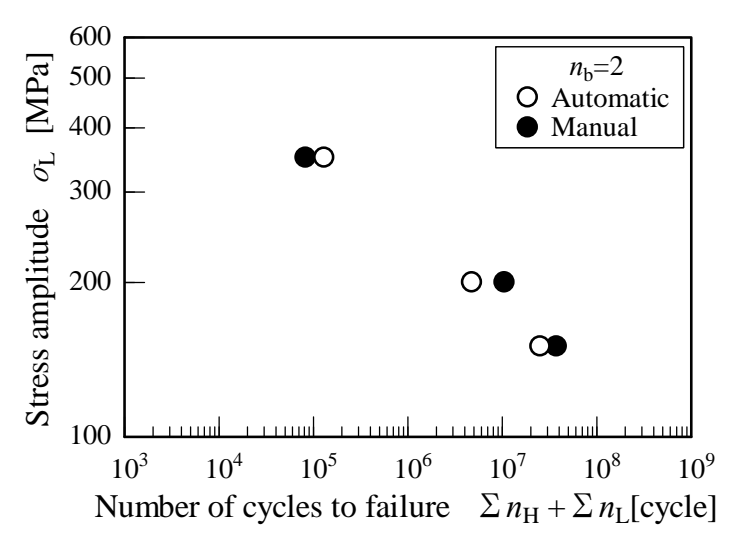

(a) $n_{\mathrm{b}}=2$

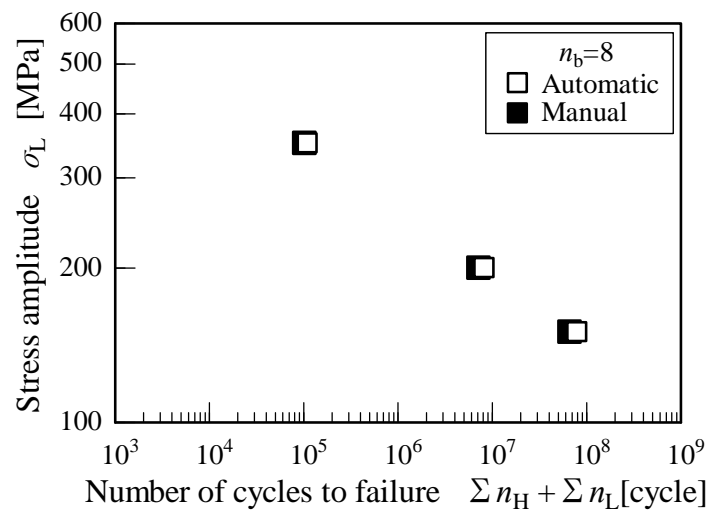

(b) $n_{\mathrm{b}}=8$

Fig.8 Relationship between lower stress amplitude and total number of cycles to failure. The total fatigue life is good agreement in both procedures. It is shown that the performance of the loading apparatus is sufficient for tests. 
返し数 $\left(\sigma_{\mathrm{H}}\right.$ の総繰返し数 $\Sigma n_{\mathrm{H}}$ と $\sigma_{\mathrm{L}}$ の総繰返し数 $\Sigma n_{\mathrm{L}}$ との和）の関係を示寸. 図より今回自作した自動負荷装置を 用いた試験結果と手動により荷重を変動させた場合の結果がほぼ一致していることがわかる. なお, 後述の $3 \cdot 3$ で示すが, $n_{\mathrm{b}}=4$ の場合にも自動負荷装置と手動で荷重を切替えた試験結果で良い一致が認められた. つまり, 自 動負荷装置が十分な性能を有していることが確かめられた. また, 二段多重変動荷重疲労試験の場合には, $S-N$ 曲 線から求められた疲労限度よりも大きな高応力振幅を繰返すため, 試験が非破断で終了することはない，なお， 今回は手動による試験もあわせて行い，両方法による試験結果をまとめて整理した.

\section{$3 \cdot 3$ 二段多重変動荷重疲労試験}

高一低二段二重変動荷重下の疲労寿命（=破断繰返し数）を推定し，その繰返し数を分割数 $n_{\mathrm{b}}$ で除することに より，試験条件を設定した．そこでまず，繰返す変動荷重の繰返し数を分割することによる疲労寿命への影響を 二段多重変動荷重疲労試験の結果と高一低二段二重変動疲労寿命の推定結果と比較することにより考察し, その 後, 二段多重変動荷重下の疲労寿命評価について検討する.

\section{$3 \cdot 3 \cdot 1$ 高一低二段二重変動荷重疲労試験との比較}

二段多重変動荷重疲労試験の結果を図 9 に示寸. 縦軸は低応力振幅 $\sigma$ であり, 横軸は高応力振幅 $\sigma_{\mathrm{H}}$ の総繰 返し数 $\Sigma n_{\mathrm{H}}$ および低応力振幅 $\sigma$ の 総繰返し数 $\Sigma n_{\mathrm{L}}$ である. 図中の実線は, 前述の $3 \cdot 2$ で示した方法により推定し た高一低二段二重変動疲労寿命の推定結果である．また，破線はその有限寿命域を示寸直線を延長したものであ

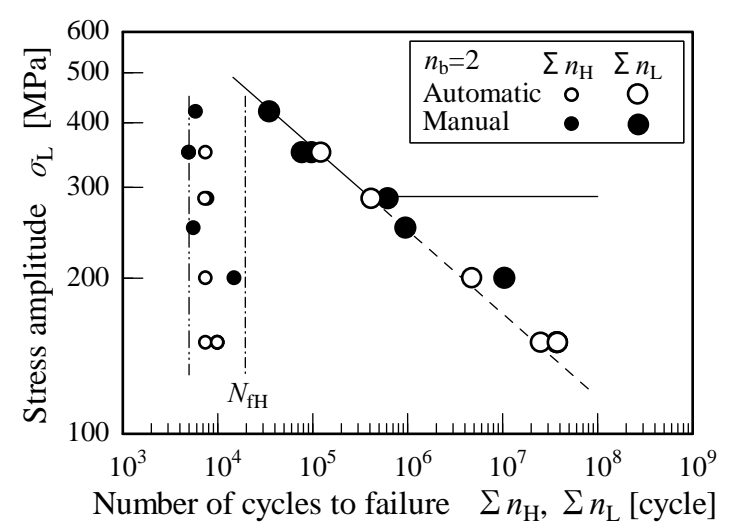

(a) $n_{\mathrm{b}}=2$

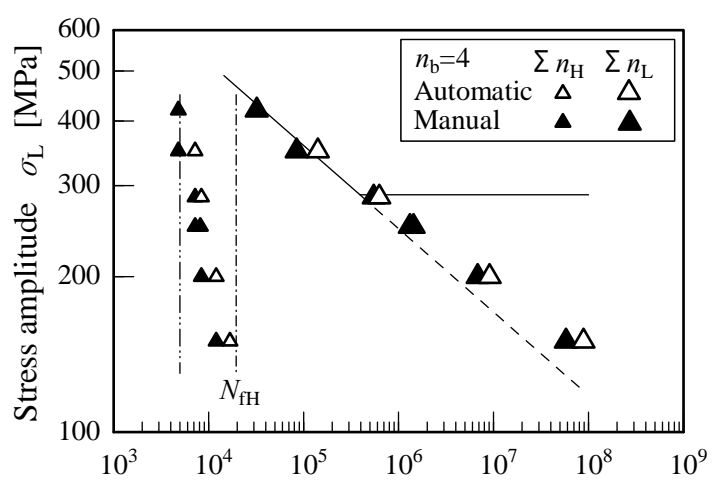

Number of cycles to failure $\sum n_{\mathrm{H}}, \sum n_{\mathrm{L}}$ [cycle]

(b) $n_{\mathrm{b}}=4$

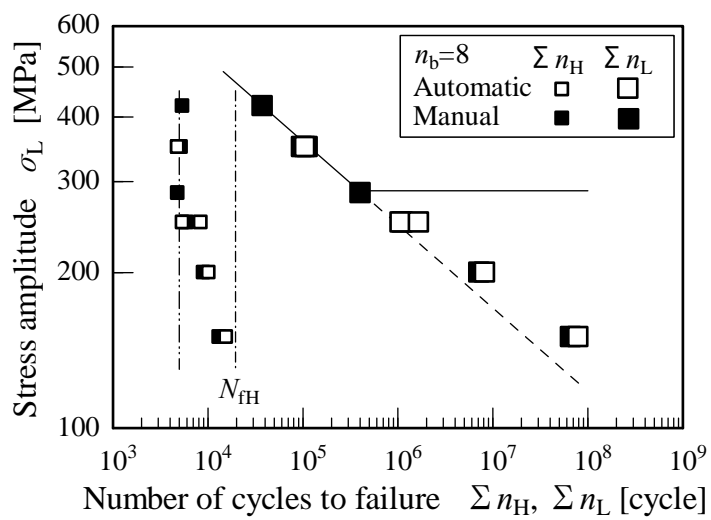

(c) $n_{\mathrm{b}}=8$

Fig.9 Relationship between lower stress amplitude and total number of cycles of each stress amplitude to failure. The fatigue lives under lower stress amplitude are longer than the estimated lives below about 300MPa. 


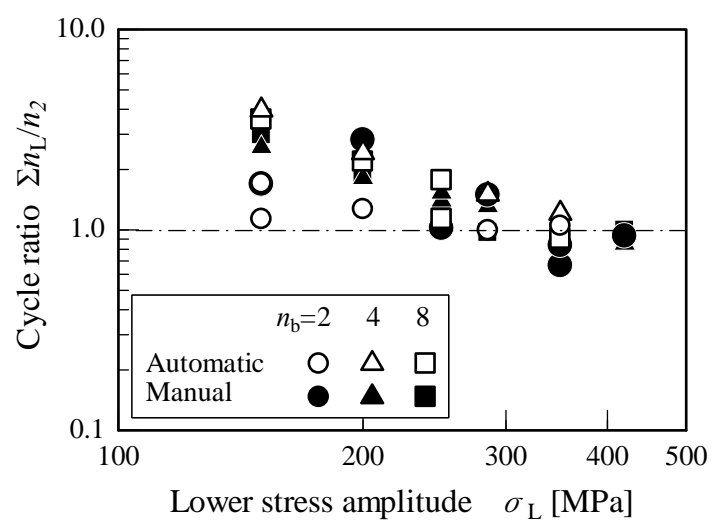

Fig.10 Relationship between lower stress amplitude and cycle ratio of experimental results to estimated ones. Cycle ratio becomes larger than 1 as the lower stress amplitude decreases.

る. 図中の一点鎖線は $\sigma_{\mathrm{H}}=490 \mathrm{MPa}$ のみを繰返した場合の疲労寿命 $N_{\mathrm{fH}}$ を，二点鎖線は $D_{1}=0.256$ に相当する繰 返し数 5000 回を示している. 図からわかるように， $\Sigma n_{\mathrm{H}}$ は， $\sigma_{\mathrm{L}}$ が小さくなると， $N_{\mathrm{fH}} に$ 近づく傾向が見られる. また， $\Sigma n_{\mathrm{L}}$ をみると，実線およびそれを延長した破線で示寸高一低二段二重変動疲労寿命の推定結果と $\sigma_{\mathrm{L}}=285$ MPa 以上ではほぼ一致しているが， $\sigma_{\mathrm{L}}=285 \mathrm{MPa}$ 以下になると破線に比べて試験結果は寿命が長くなっている. つまり, 推定された二段二重変動疲労寿命を分割して応力振幅を繰返した場合， $\sigma_{\mathrm{L}}$ が大きい場合には繰返し数の

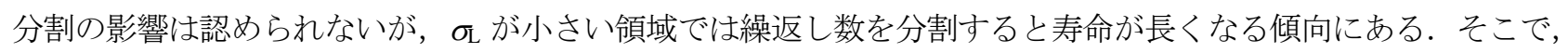
高一低二段二重変動疲労寿命の推定結果と二段多重変動荷重疲労試験の結果の比を $\sigma_{\mathrm{L}}$ との関係で整理すると, 図 10 のようになる. 図からわかるように，推定結果と試験結果の比は，ばらつきはあるものののが $285 \mathrm{MPa}$ 境に，それ以上ではほぼ 1 であるが， $\sigma_{\mathrm{L}}$ が $285 \mathrm{MPa}$ より小さくなるとともに 1 より大きくなっている.また，分 割数 $n_{\mathrm{b}}$ が 4 および 8 の場合には， $n_{\mathrm{b}}$ が 2 の場合に比べ，その比が大きくなっていることもわかる．S45C 調質材 を用いた一定振幅荷重下の回転曲げ試験において，き裂の発生時期は疲労寿命の 30\%程度であることが報告され ている（後藤他, 1989). したがって, 今回行った試験においても疲労寿命の大半がき裂進展寿命であると考えら れる. そこで, $n_{\mathrm{b}}=2$ および 8 の場合について, き裂進展を検討した結果, 同様の傾向が認められたため, ここで は， $n_{\mathrm{b}}=2$ の場合のき裂伝ぱ曲線を図 11 に示す．横軸はき裂発生後の繰返し数である. 図より， $\sigma_{\mathrm{H}}=490 \mathrm{MPa}$ から $\sigma_{\mathrm{L}}=420 \mathrm{MPa}$ に切替えた場合には， $\sigma_{\mathrm{L}}$ の下でもき裂は進展しているが， $\sigma_{\mathrm{H}}=490 \mathrm{MPa}$ から $\sigma_{\mathrm{L}}=150 \mathrm{MPa}$ に切替えた 場合には，き裂がわずかしか進展していないことがわかる．つまり， $\sigma_{\mathrm{L}}=420 \mathrm{MPa}$ に切替えた場合には， $\sigma_{\mathrm{H}} に よ$

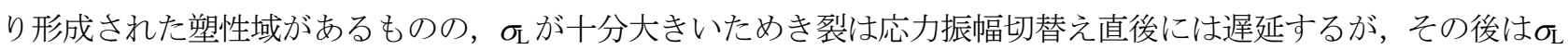

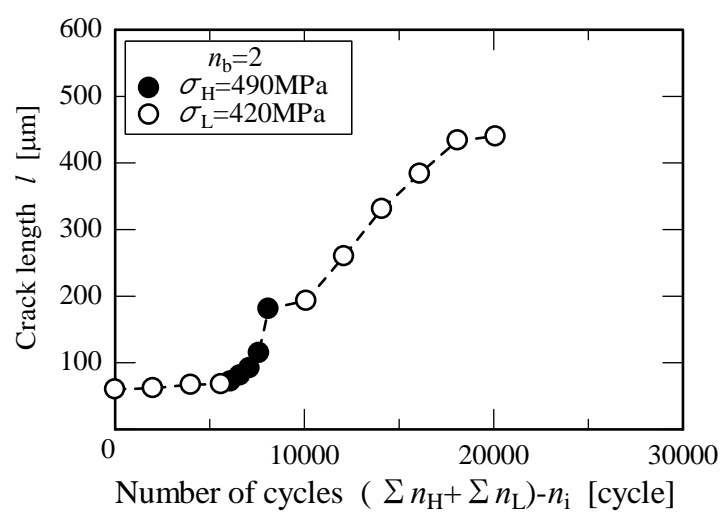

(a) $\sigma_{\mathrm{L}}=420 \mathrm{MPa}$

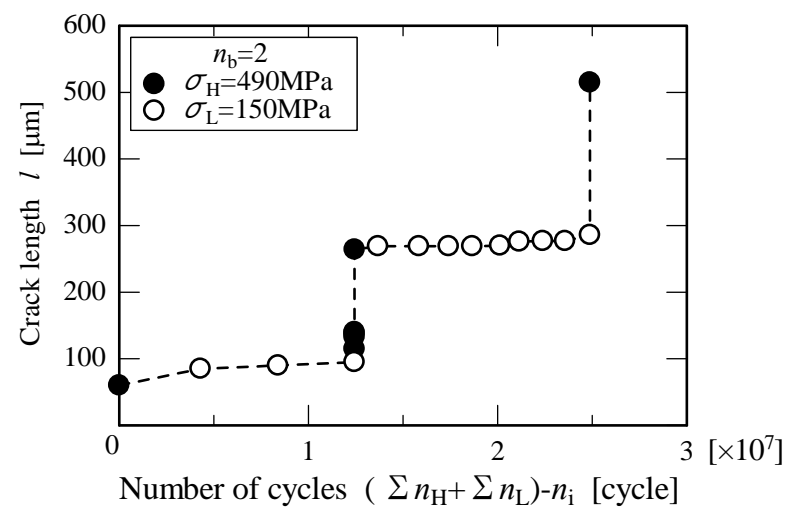

(b) $\sigma_{\mathrm{L}}=150 \mathrm{MPa}$

Fig.11 Crack propagation curves. The crack hardly propagates in case that the low stress amplitude is 150MPa. 
の繰返しとともに進展したと思われる，一方， $\sigma_{\mathrm{L}}=150 \mathrm{MPa}$ に切替えた場合には， $\sigma_{\mathrm{H}}$ にり形成された塑性域に よりき裂がほとんど進展しないため, $\sigma_{\mathrm{L}}$ の下でもき裂が進展すると仮定し, 高一低二段二重変動疲労寿命を推定 して延長した破線に比べ，寿命が長くなったと考えられる．また， $\sigma_{\mathrm{L}}$ が小さくなると， $\sigma_{\mathrm{H}}$ での塑性域の影響でき 裂が進展しにくくなり，き裂の進展に及ぼす $\sigma_{\mathrm{L}}$ の影響が小さくなったため， $\sigma_{\mathrm{H}}$ の総繰返し数が $\sigma_{\mathrm{H}}$ のみを繰返し た場合の疲労寿命に近づいたものと思われる。

\section{$3 \cdot 3 \cdot 2$ 二段多重変動荷重下における疲労寿命評価}

著者の一人は, 転造対じ継手の二段多重変動荷重疲労試験における破断条件を式（1）のように仮定した（瀬戸 口他，2000)。ここで， $D_{\mathrm{i}}$ はそれまでの累積疲労損傷值， $d_{\mathrm{i}}$ はある応力振幅 $\sigma_{\mathrm{i}}$ の繰返しによる疲労損傷值， $\alpha_{\mathrm{i}}$ は負 荷履歴と材料特性を考慮した係数である.また， $N_{\mathrm{fi}}$ はそのときに繰返される応力振幅 $\sigma_{\mathrm{i}}$ に対する破断寿命， $n_{\mathrm{i}}$ は その応力振幅の繰返し数である. $\alpha_{\mathrm{i}}=1$ の場合にはマイナー則あるいは修正マイナー則と一致する.

$$
\begin{aligned}
& D_{\mathrm{i}}=\sum_{\mathrm{j}=1}^{\mathrm{i}} d_{\mathrm{j}}=1 \\
& \text { ここで, } \\
& d_{\mathrm{i}}=\alpha_{\mathrm{i}} \frac{n_{\mathrm{i}}}{N_{\mathrm{fi}}}
\end{aligned}
$$

この考え方を二段二重変動疲労の場合に適用すると，式（2）のように表される.

$$
\alpha_{1} \frac{n_{1}}{N_{\mathrm{f} 1}}+\alpha_{2} \frac{n_{2}}{N_{\mathrm{f} 2}}=1
$$

同じ応力振幅を繰返す場合には， $\alpha_{1}=1$ となること，および $n_{2}$ が高一低二段二重変動荷重疲労試験の場合の二 次応力振幅に対する疲労寿命に対応することを考慮すると， $\alpha_{2}$ は式（3）のように表される（瀬戸口他，2000）.

$$
\alpha_{2}=\left(\frac{\sigma_{1}}{\sigma_{2}}\right)^{4.20 D_{1}}
$$

これを任意の $i$ に対しても， $\alpha_{\mathrm{i}}$ が同様の式で表されると仮定すると， $\alpha_{\mathrm{i}}$ は式 (4) のように与えられる.

$$
\alpha_{\mathrm{i}}=\left(\frac{\sigma_{\mathrm{i}-1}}{\sigma_{\mathrm{i}}}\right)^{4.20 D_{\mathrm{i}-1}}
$$

この評価方法で疲労寿命評価を行った場合, 推定精度が悪く, $\sigma_{\mathrm{L}}$ が低下寸るとともに実験結果との差が大きく なり，疲労寿命を短く予測する傾向となった，そこで，係数 $\alpha_{\mathrm{i}}$ について詳細に検討した．その結果，応力振幅が 切り替わるときの累積疲労損傷に対して図 7 より求めた二段二重変動疲労の場合の非破断の上限值 $\sigma_{\mathrm{w}}$ と次に繰 返される応力振幅を比較し, 次に繰返される応力振幅の方が大きい場合は, 式 (4) の $\alpha_{\mathrm{i}}$ を用い, 小さい場合は $\alpha_{\mathrm{i}}=1$ とすることにより良い推定結果が得られた. これは, 図 11 からわかるように, 繰返される低応力振幅が小さ 


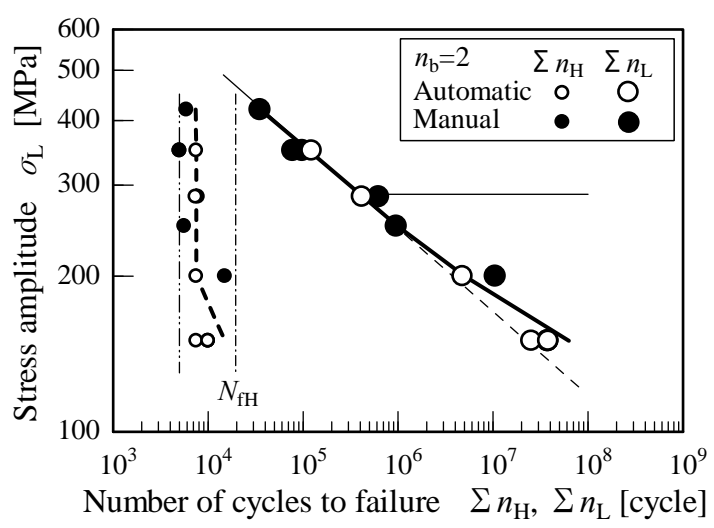

(a) $n_{\mathrm{b}}=2$

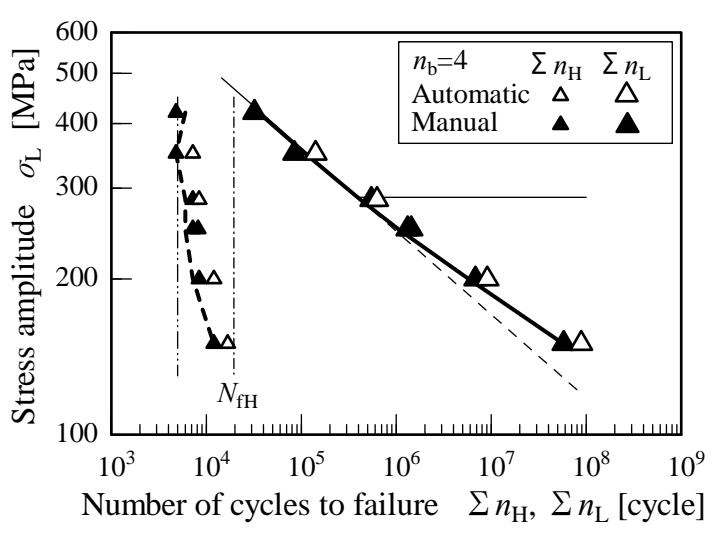

(b) $n_{\mathrm{b}}=4$

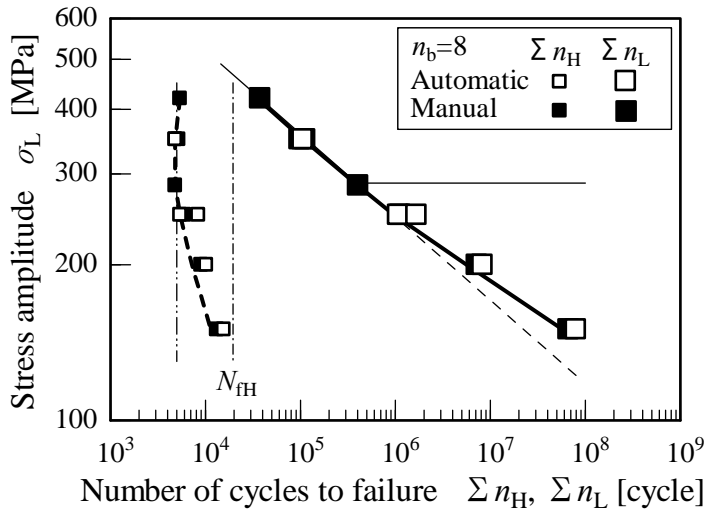

(c) $n_{\mathrm{b}}=8$

Fig.12 Relationship between lower stress amplitude and total number of cycles of each stress amplitude to failure. The estimated fatigue lives (the thick solid line and the thick broken line) are good agreement with the experimental results.

い場合には，き裂がほとんど進展しないため大きな損傷を与えていないと思われる，そこで， $\alpha_{\mathrm{i}}$ を式 (4) で求めると損傷を実際より大きく評価するのに対して， $\alpha_{\mathrm{i}}=1$ とすることにより妥当な損傷評価が行われた ためと思われる.

以上の方法により推定した高応力振幅 $\sigma_{\mathrm{H}}$ および低応力振幅 $\sigma_{\mathrm{L}}$ に対する疲労寿命 $\Sigma n_{\mathrm{H}}$ および $\Sigma n_{\mathrm{L}}$ を示したものが 図 12 である. 図中の太い破線および太い実線が推定結果である. 図より推定結果は, 高応力振幅および低応力振 幅のいずれの試験結果ともほぼ一致していることがわかる.

次に，実働荷重下の疲労を考える場合に広く用いられている修正マイナ一則に基づき，式（5）のように表され る破断時の累積疲労損傷值 $D_{\mathrm{f}}$ について検討寸る.

$$
D_{\mathrm{f}}=\frac{\sum n_{\mathrm{H}}}{N_{\mathrm{fH}}}+\frac{\sum n_{\mathrm{L}}}{N_{\mathrm{fL}}}
$$

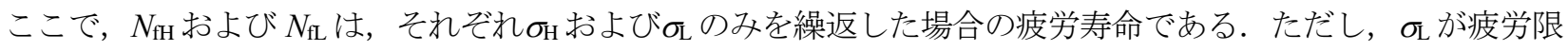
度より低い場合には，有限寿命域の $S-N$ 曲線を疲労限度以下まで延長し，仮想的な疲労寿命として求めた.

図 13 に累積疲労損傷值の試験結果と今回推定した疲労寿命から求めた累積疲労損傷值の推定結果を示す. 図 より, 試験結果をみると, $n_{\mathrm{b}}=2$ の場合にはばらつきは大きいものの, 多くの $D_{\mathrm{f}}$ は 1 より小さく, 0.6 程度になる こともあることがわかる． $n_{\mathrm{b}}=4$ および 8 の場合には， $\sigma_{\mathrm{L}}$ が $285 \mathrm{MPa}$ より小さいと $D_{\mathrm{f}}$ は 1 より大きく， $\sigma_{\mathrm{L}}$ が 285 


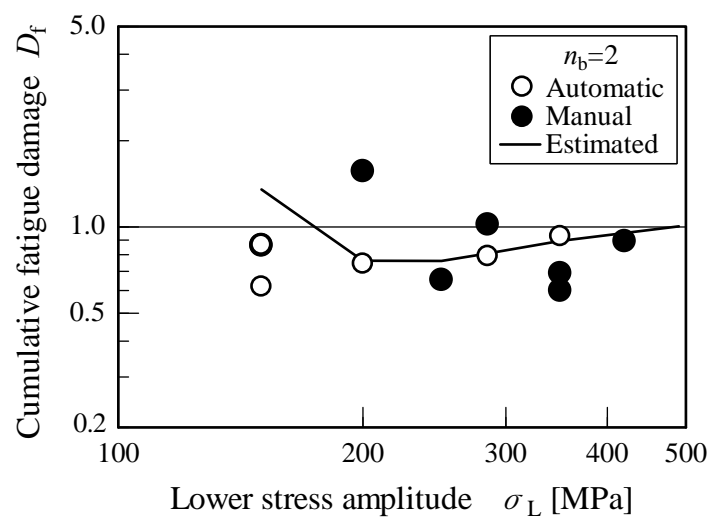

(a) $n_{\mathrm{b}}=2$

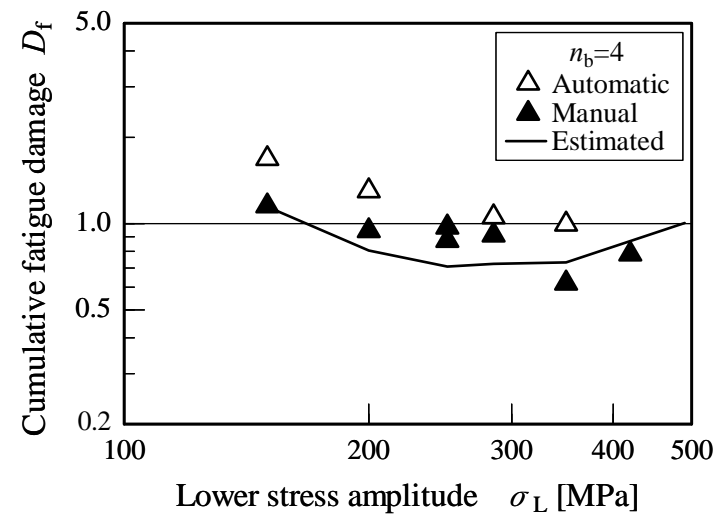

(b) $n_{\mathrm{b}}=4$

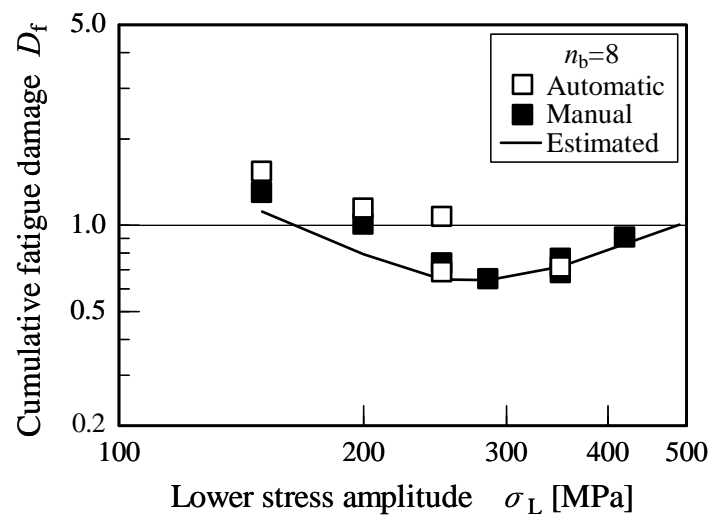

(c) $n_{\mathrm{b}}=8$

Fig.13 Relationship between lower stress amplitude and cumulative fatigue damage. The estimated cumulative fatigue damage (solid line) is good agreement with the experimental results for $n_{\mathrm{b}}=4$ and 8 .

$\mathrm{MPa}$ より大きくなると $D_{\mathrm{f}}$ は 1 より小さくなることがわかる．つまり， $n_{\mathrm{b}}$ および $\sigma_{\mathrm{L}}$ の大きさにより，修正マイ ナ一則による予測寿命より実際の寿命が短くなるということである. 推定結果をみると， $n_{\mathrm{b}}=2$ の場合には試験結 果のばらつきが大きいため，両者の対応が認められないが， $n_{\mathrm{b}}=4$ および 8 の場合には，推定結果は試験結果と同 様な傾向を示し，試験結果とほぼ対応していることがわかる. さらに，推定結果は全体として安全側の推定とな っていることもわかる. したがって, 繰返される応力振幅が頻繁に切り替わるような場合について本方法で疲労 寿命を評価すると, 安全側の寿命予測ができ, 機器等の安全性が保たれるものと思われる.

\section{4. 結 言}

S45C 調質材を用いて二段多重変動荷重下の疲労試験を行い，応力振幅の切替え頻度の影響について検討する とともに疲労寿命評価を行い, 以下の結果が得られた.

（1）二段二重変動荷重疲労試験の結果を基に繰返し数を分割し二段多重変動荷重疲労試験を行うと, 低応力振 幅が低くなるとともに，疲労寿命は分割数によらず，二段二重変動疲労寿命より長くなった.

（2）二段多重変動疲労寿命の推定を試み，試験結果とほぼ一致することが認められた.

（3）二段多重変動荷重疲労試験の結果を破断時の累積疲労損傷值で整理すると, 累積疲労損傷值は分割数と低 応力振幅の大きさにより 1 より小さくなり，修正マイナ一則による推定寿命より短寿命となる場合があった. ま た，今回推定した疲労寿命から求めた累積疲労損傷值の推定結果は試験結果とほぼ対応することが認められた. 


\section{文献}

後藤真宏, 西谷弘信, 柳川恭廣, 宮川浩臣, S45C 調質平滑材の二段二重重複応力下における疲労被害, 日本機械学 会論文集 A 編, Vol.55, No.511 (1989), pp.453-459.

川久保政洋, 釜谷昌幸, 変動荷重下における 316 ステンレス鋼の疲労寿命予測, 材料, Vol.60, No.10 (2011), pp.871878.

菊川真, 城野政弘, 宋智弘, 実働荷重下の繰返し塑性ひずみと累積疲労損傷（疲労限度以下の領域における限界修 正 $S-N$ 曲線），材料, Vol.23, No.252 (1974), pp.743-750.

Miner, M.A., Cumulative damage in fatigue, Journal of Applied Mechanics (1945), pp.A159-164.

村上教宜, 松田健二, 過小応力を含む 2 段繰返し疲労試験の寿命予測における微小き裂の役割, 材料, Vol.36, No.409 (1987), pp.1065-1070.

Murthy, A.R.C., Palani, G.S. and Iyer, N.R., State-of-the-art review on fatigue crack growth analysis under variable amplitude loading, IE (I) Journal CV, Vol.85 (2004), pp.118-129.

瀬戸口克哉, 高瀬徹, 中村匡宏, 村上寛和, 転造䍩じ継手の二段多重疲労寿命の推定, 日本機械学会論文集 A 編, Vol.66, No.650 (2000), pp.1872-1877.

高瀬徹, S45C 調質材の二段二重変動荷重下の回転曲げ疲労寿命評価, 日本機械学会論文集 A 編, Vol.75, No.751 (2009), pp.322-326.

\section{References}

Goto, M., Nisitani, H., Yanagawa, Y. and Miyagawa, H., Fatigue damage of heat-treated $0.45 \%$ C steel plane specimens under two-step loading, Transactions of the Japan Society of Mechanical Engineers, Series A, Vol.55, No.511 (1989), pp.453459 (in Japanese).

Kawakubo, M. and Kamaya, M., Fatigue life prediction of stainless steel under variable loading, Journal of the Society of Materials Science, Japan, Vol.60, No.10 (2011), pp.871-878 (in Japanese).

Kikukawa, M., Jono, M. and Song, J., The cyclic plastic strain and cumulative fatigue damage under actual loadings (Critical modified $S-N$ curve in the region below fatigue limit), Journal of the Society of Materials Science, Japan, Vol.23, No.252 (1974), pp.743-750 (in Japanese).

Miner, M.A., Cumulative damage in fatigue, Journal of Applied Mechanics (1945), pp.A159-164.

Murakami, Y. and Matsuda, K., Role of small cracks and understress in prediction of fatigue life under two-step stress loading, Journal of the Society of Materials Science, Japan, Vol.36, No.409 (1987), pp.1065-1070 (in Japanese).

Murthy, A.R.C., Palani, G.S. and Iyer, N.R., State-of-the-art review on fatigue crack growth analysis under variable amplitude loading, IE (I) Journal CV, Vol.85 (2004), pp.118-129.

Setoguchi, K., Takase, T., Nakamura, M. and Murakami, H., Life prediction of rolled bolt-nut joints under two-level multi-step loading, Transactions of the Japan Society of Mechanical Engineers, Series A, Vol.66, No.650 (2000), pp.1872-1877 (in Japanese).

Takase, T., Estimation of fatigue life on heat-treated $0.45 \% \mathrm{C}$ steel under two-step rotating bending, Transactions of the Japan Society of Mechanical Engineers, Series A, Vol.75, No.751 (2009), pp.322-326 (in Japanese). 